\title{
Igwebuike as a Trend in African Philosophy
}

\author{
Ikechukwu Anthony, KANU \\ Augustinian Institute, Makurdi, Nigeria
}

\begin{abstract}
The debate on what constitutes African philosophy, which has been divided into trends or schools dates back to the 1960s and 70s. This was a time when African thinkers began to question the perspective that traditional African beliefs and worldviews, as embedded in pre-colonial African cultures constituted African philosophy. From the arguments of these African thinkers emerged the Universalist trend, Particularist trend, National-Ideological trend, sage philosophy, Literary Philosophy and Hermeneutic trend. This notwithstanding, with the new developments in the area of African philosophy, this piece argues that there is the need for another trend of African philosophy that is multidimensional in character and which reflects the ontological character of the African worldview. The multidimensional approach would be employed in this study. Igwebuike as a trend would, therefore, be a central point or a point of convergence for all the trends of African philosophy. With Igwebuike it is hoped that the tension between particularity and university would be balanced.
\end{abstract}

Keywords: Igwebuike, Igwebuikology, Trend, School, African, Philosophy.

\section{Introduction}

As decades overtook decades, new methods of interpreting the African philosophical experience emerged. In an earlier work I wrote on The Trends in African philosophy, published in the filosophiaTheoretica: Journal of African Philosophy, Religion and Culture, I categorized and discussed the trends or schools of African philosophy into the universalist trend, particularist trend, the eclectic school, national-ideological trend, sage philosophy, literary school and Hermeneutic trend.I explained that the universalist or professional school of African philosophy argues that philosophy is the same everywhere and uses the same methodology, and thus, African philosophy should be critical and not a descriptive record of Africa beliefs. Bodunrin (cited by Uduigwomen, 1995), a strong member of this school of thought, therefore, holds that "Philosophical systems are built up by systematic examination of specific features of the world out of the relationships that are perceived to obtain between them" (p. 3). Uduigwomen, (1995) criticizes this school on the grounds that philosophical problems will remain plain and in the abstract except they are made to have local and concrete relevance. The universalist school, therefore, places philosophy at the ivory tower, and makes her an abstract discipline without concrete historical experience.

The particularist school or ethno-philosophy was championed by scholars likeTempels (1969), Mbiti (1969) and Senghor $(1964 ; 1973)$. They hold that the different African worldviews properly constitute what could be regarded as African philosophy. They would define African Philosophy as the philosophical thought of Africans as could be culled from their various worldviews, myths, proverbs, etc. In this sense, it is the philosophy indigenous to Africans, untainted by foreign ideas. Hountondji (1995) and Segun (1995) criticize the particuarist school on the basis of its definition of African philosophy in terms that are traditional and because of its emphasis on the particular. Already, between the universalist school and the particularist school, one begins to notice and feel the tension between particularity and universality, and thus, the need for the balancing of this tension.

Added to these two major schools are: the National Ideological School which focuses on discourses of African political thinkers like Azikiwe, Nyerere, Awolow, etc. It was the theoretical offshoot of the African anti-colonial struggle. It is a school that focuses on a particular historical experience in Africa. There is also the Sage School. Itwas developed by the Kenyan philosopher, Henry Odera Oruka (1944-1995). He interviewed sages from traditional groups and identified philosophical sages in different cultures who were more of the repositories of cultural wisdom. Oruka (1991) divided them into two groups; the first he called Folk Sages, who embodied community wisdom; the second he called Philosophical Sages, who held a critical stand towards that wisdom. From his findings, especially as to philosophical sages, he concluded that the West and Hountondji were wrong in saying that Africa has no philosophy, for his research showed that philosophy existed in traditional Africa. The last schools are Literary/Artistic school and the hermeneutic school. While the literary trend focuses on African 
thinkers who through their literary or artistic works made philosophical contributions, the Hermeneutic school sees the primary function of African philosophy as interpretation. A view expressed in the works of Okere (1983), Madu (1992) and Serequeberhan (1994). A cursory glance at these different schools of African philosophy reveals that the tension between particularity and universality still remains unresolved. There is off course a thesis, but there is need for a synthesis that a thesis may be born. This piece argues that Igwebuike is the school that would make a difficult synthesis of the extremes of the universalist and particularist school for the forging ahead of the African philosophical enterprise.

\section{The Complementary Nature of the African Reality as a Basis for an Eclectic School of African Philosophy}

The fundamental principle which describes the core of the African spirit is harmony; although reality exists as individuals, they converge at the point of reasonableness. It is therefore, not surprising that Asouzu (2007b) in his complementary philosophy of Ibuanyidanda, would present the African reality as "an all-embracing whole, in which all units form together a dynamic play of forces, which are in harmony with each other, by completing and supporting the other" (p. 14). Asouzu (2004) further speaks of reality as "necessary complements of each other" (46). While describing the human society, Asouzu (2007a) advanced that, "Human beings and societies exist only in relations" (p. 74). Thus, the point of convergence is a natural process of world history and a phase in the world historical process. Asouzu (2007a) describes it as "a necessary consequence of the character of our being as relative subjects seeking full actualization" (p. 382). This understanding of reality is the ontological foundation for an eclectic school of African philosophy. This is also the basis for the construction a school of African philosophy that would help the exclusive universalist and particularist schools to come together, complement one another and harness their positive energies for the evolution of African philosophy.

\section{Igwebuike as an Eclectic Ontologico-Existential Trend}

'To be' in Igbo ontology is idi. However, the modality of being according to Kanu (2014a) is Igwebuike. Kanu (2014b) avers that Igwebuike is an Igbo word, which is a combination of three words. Thus, it can be understood as a word and as a sentence: as a word, it is written thus, Igwebuike, and as a sentence, it is written as, Igwebuike, with the component words enjoying some independence in terms of space. Let us try to understand the three words involved: Igwe is a noun which means number or population, usually a large number or population. $B u$ is a verb, which means is. Ike is a noun, which means strength or power. Put together, it means 'number is strength' or 'number is power', that is, when human beings come together in solidarity and complementarity, they are powerful or can constitute an insurmountable force. At this level, no task is beyond their collective capability. Kanu (2015) argues that this provides an ontological horizon that presents being as that which possesses a relational character of mutual relations. As an ideology, Igwebuike rests on the African principles of solidarity and complementarity. It argues that 'to be' is to live in solidarity and complementarity, and to live outside the parameters of solidarity and complementarity is to suffer alienation. 'To be' is 'to be with the other', in a community of beings. This is based on the African philosophy of community, which is the underlying principle and unity of African Traditional Religious and philosophical experience.

It is from this background that this school of African philosophy derives its name. It is ontological and existential in character, and in this way, it makes a difficult synthesis of the basic and positive elements of the universalist school and particularist school for the generation of a new thesis for African philosophy. As Igwebuike means "there is strength in unity", it believes that the harnessing of the positive energies of the universalist and particularist schools would bring about the advancement of African philosophy. Ontologically, it emphasizes the universal character of philosophy, existentially,it respects the regional character of African philosophy, that is, its Africanness, with Africa being the locale for the philosophical investigation. It strongly believes that universality and particularity are congenial in the sense that they need each other to remain germane and perennial, to remain contextually intelligible and of standard universally.

The Igwebuike school of African philosophy would define African Philosophy as the combination of the universalist and particularist approaches to African philosophy. This would involve sifting the philosophical thought of Africans as could be gotten from their various world views, myths, proverbs, etc, and reflecting on them by an African genius, that is, the African philosophers. At the point of romance between the professional 
and unprofessional, authentic African philosophy is realized. Although the different schools are already doing African philosophy, but that they will do better if they join heads together. Uduigwomen, (1995) describes the positive possible outcome of the Igwebuike school as follows:

The universalist approach will provide the necessary analytic and conceptual framework for the particularist school. Since this framework cannot thrive in a vacuum, the particularist approach will supply the raw material or data needed by the universalist approach. Thus, it will deliver the universalist approach from mere logic-chopping and abstractness. There will be a fruitful exchange of categories and concepts. (p. 6).

The Igwebuike school of African philosophy can be referred to as an eclectic school or moderate trend, and from my own estimation, it is a balanced and safer path to thread in doing African philosophy.

\section{Conclusion}

In 2013, when I madea case for the eclectic school, scholars like Mangena (2014) had argued that the move towards an eclectic school of African philosophy is "a disservice to our very own philosophy called ethnophilosophy" (p. 96). He interpreted this move as running away from my burning house only to seek refuge next door. As I read through his paper, I asked myself a couple of questions: is t reasonable to remain in a burning house and die in it? Is it not safer to take refuse in a safe place? If a human being clings onto something simply because it is his own and not because it is reasonable, does it not degenerate into emotionalism? At this level is it still philosophy? African philosophy is not static, and must not be eternally anchored on folklores, proverbs and myths. The world is globalizing, and new realities are emerging on the table of African philosophy; it would rather be a disservice to African philosophy if African philosophers would reduce African philosophy to only reflection on myths, folklores, proverbs, symbols etc. if this is done, the aperture for growth would have been closed. No school of African philosophy is complete; growth begins when we begin to seek completeness, and the different schools of African philosophy complete the other.

\section{References}

[1] Asouzu, I. I. (2004) The methods and principles of complementary reflection in and beyond African philosophy. Calabar: University of Calabar Press

[2] Asouzu, I. I. (2007a). Ibuanyidanda: New complementary ontology. Beyond world immanentism, ethnocentric reduction and impositions. Munster: Lit Verlag.

[3] Asouzu, I. I. (2007b). Ibuaru: the heavy burden of philosophy, beyond African philosophy. Studies in African philosophy series. Munster: Lit Verlag.

[4] Hountondji, P. (1995). African philosophy: Myth and reality. Paris: Francois Maspero.

[5] Kanu, I. A. (2013). Globalisation, globalism and African philosophy. Germany: Lambert.

[6] Kanu, I. A. (2014). Igwebuikology as an Igbo-African philosophy for Catholic-Pentecostal relations. Jos Studies. 22. 87-98.

[7] Kanu, I. A. (2014). Igwebuike as an Igbo-African Philosophy for Interreligious Dialogue. A Paper presented at the Nigerian Philosophical Association National Conference, held at the University of Lagos, Lagos State, October 1517.

[8] Kanu, I. A. (2015). Igwebuike as an Igbo-African Philosophy for National Unity. A paper presented at the 2015 International Conference of the Faculty of Arts, Nnamdi Azikwe University, Awka, Anambra State. Held on 17-19 June.

[9] Madu, R. O. (1992). African symbols, proverbs and myths: The hermeneutics of destiny. Frankfurt: Peter Lang.

[10] Mbiti, J. (1969). African religions and philosophy. Nairobi: East African Educational Publishers.

[11] Okere, T. (1983). African philosophy: A historico-hermenuetical investigation of the conditions of its possibility. Lanham: University Press America.

[12] Oruka, H. O. (1991). Sage philosophy: Indigenous thinkers and modern debate on African philosophy. Nairobi: African Center for Technological Studies (ACTS)).

[13] Segun, G. (1995). African philosophy: Traditional Yoruba philosophy and contemporary African realities. London: Peter Lang.

[14] Senghor, L. (1964). On African socialism. New York: F. A. Praeger. 
[15] Senghor, L. (1975). What is negritude? In G. C. M. Mutiso and S. W. Rohio (Ed.s). Readings in African political thought. London: Heinemann.

[16] Serequeberhan, T. (1994). The hermeneutics of African philosophy: Horizon and discourse. New York: Routledge. [17] Tempels, P. (1959). Bantu philosophy. Trans. Colin King, Paris: Presence Africaine.

[18] Uduigwomen, A. F. (1995). Philosophy and the place of African philosophy. In Footmarks on African philosophy (pp. 3-9). Ikeja: OOP Press.

A. F. Uduigwomen (Ed.). 